\title{
Self-Reliant Farming and Employment Opportunities for Migrant Workers Relating COVID-19 Post-Pandemic
}

\author{
Krishna Gopal Mandal*, Amod Kumar Thakur and Rajeeb Kumar Mohanty
}

ICAR- Indian Institute of Water Management, Chandrasekharpur, Bhubaneswar, Odisha, India

"Corresponding author: kgmandal@gmail.com (ORCID ID: 0000-0003-4961-3716)

Received: $16-12-2020$

Revised: $12-02-2021$

Accepted: 02-03-2021

\begin{abstract}
There has been an unprecedented crisis due to the COVID-19 pandemic. The human witnessed significant changes in all spheres of activities in the society. There was complete, partial or intermittent lockdown all over the world to contain this infectious virus. People confined themselves mostly at home, and about $60 \%$ of economic activities was disrupted. The growth in the economy slowed down. Millions of international and internal migrant workers returned to their place of origin and again resuming works. To return to the economic normalcy, challenges would be to cope up with problems of migrant workers, protecting their livelihoods and providing income through employment to avert destabilizing effects. There is a need for strategic approaches and effective policies to strengthen self-sufficiency and self-reliance among returnees, and the farmers with the support of the Government and other agencies. Thus, attempts have been made in this paper to make an account on the migrant workers, to elucidate the COVID-19 impacts on them, to appraise major strategies and policy recommendations to strengthen self-reliant farming, rural development and re-employment.

\section{Highlights}

(0 Return of migrant workers and disruption of about $60 \%$ of economic activities due to COVID-19 pandemic.

(0 Evidence-based options for employment of migrant workers and farmers through self-reliant farming in post-pandemic.
\end{abstract}

Keywords: COVID-19 post-pandemic, migrant workers, Indian agriculture, self-reliant farming, employment

The Corona Virus Disease (COVID-19) was identified first in Wuhan, China during the last December, 2019. This disease is a severe acute respiratory syndrome coronavirus-2 (SARS-CoV-2) to human (Gorbalenya et al. 2020), and the World Health Organization categorized this as a pandemic. The disease was spread to more than 212 countries across the world, except the Antarctica, in a span of 6-7 months. People witnessed an unprecedented health emergency (Chakraborty and Maity, 2020). The Americas, the Europe and Indian sub-continent was the worst affected regions. The public health became critical. The central and local Governments of all countries forced people to confine at home maintaining social distance to contain the spread of this highly infectious virus. Consequently, there was substantial disruptions in normal life and society, reversing of migrant workers; about $60 \%$ of all economic activities in the world came to a halt. The UNDP warned that COVID-19 pandemic would far more than a health crisis, it would increase poverty, inequalities among people at global scale and calls for urgent achievement of sustainable development goals- SDGs (UNDP, 2020).

How to cite this article: Mandal, K.G., Thakur, A.K. and Mohanty, R.K. (2021). Self-Reliant Farming and Employment Opportunities for Migrant Workers Relating COVID-19 Post-Pandemic. Economic Affairs, 66(1): 41-52.

Source of Support: None; Conflict of Interest: None 
The world development is closely associated with the migrant people and the workers. Migrant workers contribute significantly to the development of economy and the society. International Labour Organizations (ILO) estimates that migrant workers represent $4.7 \%$ of the global labour pool of 164 million workers (ILO, 2017 and 2020). Migrant workers serve at the front for essential jobs like health care, transport, construction, general services, agriculture, and agri-food processing industries etc. (ILO, 2020). Due to COVID-19 pandemic, migrant workers (international and national) were the worst affected. In some cases, travel restrictions forced them to remain in the destination country. Now, it is important to look into the economic conditions, food security and re-employment of the migrants, and also the farming community. There had been adverse impact on farming community also who are engaged in agri-farming and allied activities.

Therefore, attempts have been made in this paper to make an account on the migrant workers, to elucidate the impacts of COVID-19 pandemic on them and on farmers, to appraise the potential benefits of using rural youths to reinvent agriculture and rural development, and also to suggest effective approaches and policies to develop and strengthen self-reliant farming, rural economy and re-employment.

\section{MATERIALS AND METHODS}

\section{The data and information}

The secondary sources of data and information have been used in this study. The data on the stock of international total migrants (1990-2019 in five year period) were collected from the UN Department of Economic and Social Affairs, through its web source. The data on Indian internal migration were obtained from different sources viz. Economic Survey of India, World Economic Forum, published information by different authors, National Sample Survey and Census of India. The Government of India sources of latest information were used in this paper for data on overseas Indians (total of non-resident Indians and persons of Indian origin), return of migrant workers due to COVID-19 pandemic, Farmer Producer Organizations (FPOs), Self-help Groups (SHGs), food processing industries, agricultural labours, land holding categories, average holding size etc. Compilation and collation of data were made for meaningful interpretation. Some other pertinent data and information were obtained from different websites, published bulletins by International labour Organization, UNDP, WHO, FAO, IFPRI, NABARD, COVID-19 bulletins, peerreviewed papers published in referred journals, TV, media, news reported by the Press Trust of India in different electronic versions.

\section{Account on international and internal migration}

According to the latest data of UN-Department of Economic and Social Affairs, total overall stock of international migrants was 153.0 million in 1990, which increased to 271.6 million up to the mid-2019 (UNDESA 2019) (Fig. 1). The regions viz. America $(27 \%)$, Europe $(31 \%)$ and Asia (32\%) share the largest stock of migrants, and in Africa it was $10 \%$ in the year 2019 (Fig. 2). Table 1 provides the overseas Indian migration, which is also huge $(\sim 32.10$ million), spread in different regions in the world, and top 5 destinations are USA, UAE, Malaysia, Saudi Arabia and Myanmar. A considerable share of this total number is overseas migrant workers from India.

In India, the internal i.e. inter-state and intra-state migration is phenomenal. According to Economic Survey 2017 of India, inter-state migration was about 9 million every year during 2011-2016 who migrated between states for various reasons viz. employment, education, marriage and others. As per the India Census 2011 and the World Economic Forum, total number was 450 million; the most dominant migration is in the category of rural-torural migration $(47.4 \%)$ and rural-urban $(22.1 \%)$ (Table 2). This has played over many years a significant role in urbanization. About 120 million blue-collar migrants from villages moved to tier-I and tier-II cities in search of jobs like driving vehicles, delivery works, security services, housekeeping and others (Basu, 2019) (Fig. 3). About 85\% of the migrants are in the age group of 18-30 years i.e. they were young and energetic. They migrateout mostly from Uttar Pradesh, Bihar, Assam, Odisha and some other northern and north-eastern states in India. States with greater population viz. 


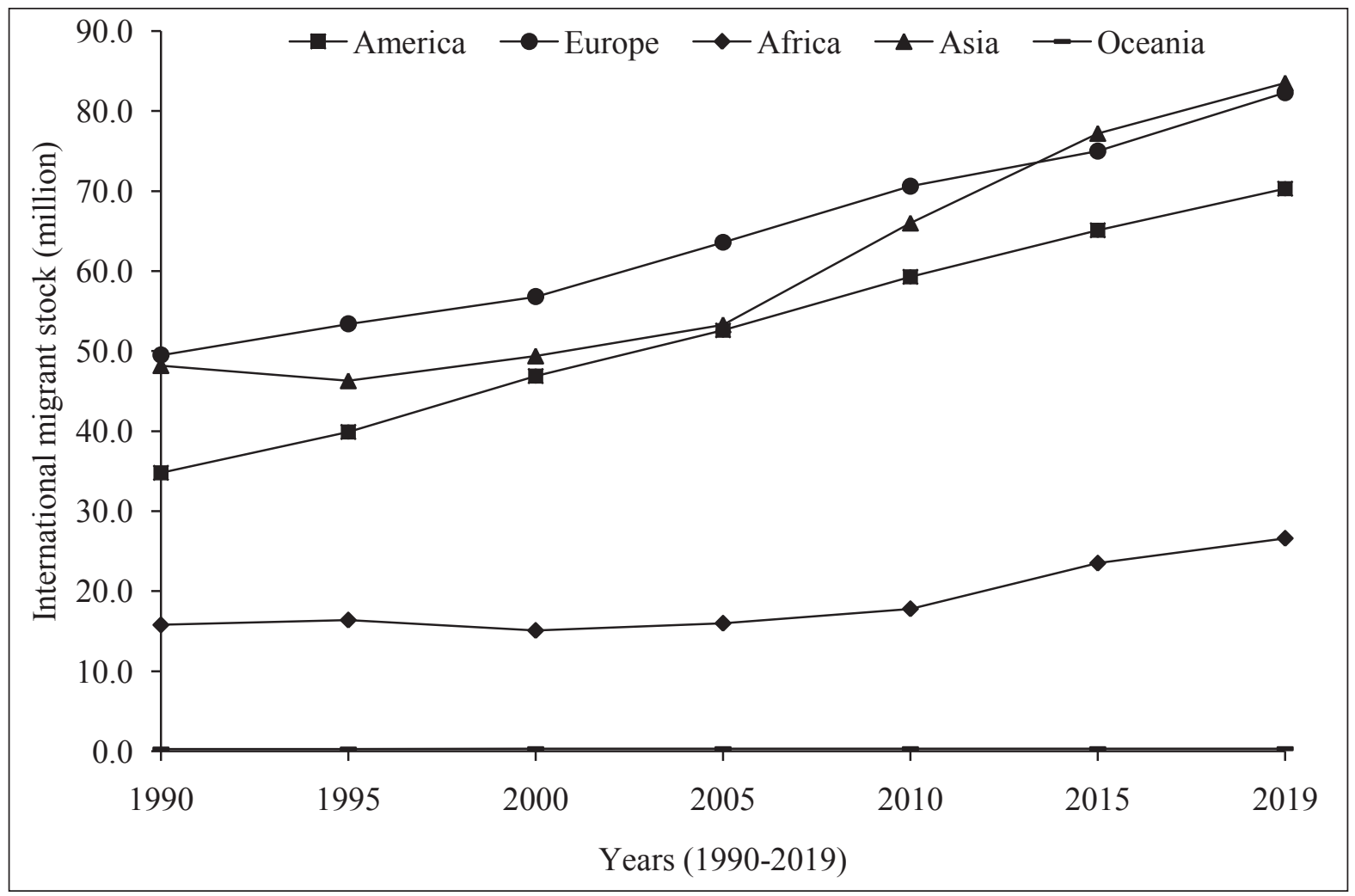

Sources: UNDESA (2019).

Fig. 1: Total international migration stock and the trends in different regions in the world over 1990-2019; includes all foreign-born residents in a country regardless of when they entered the country

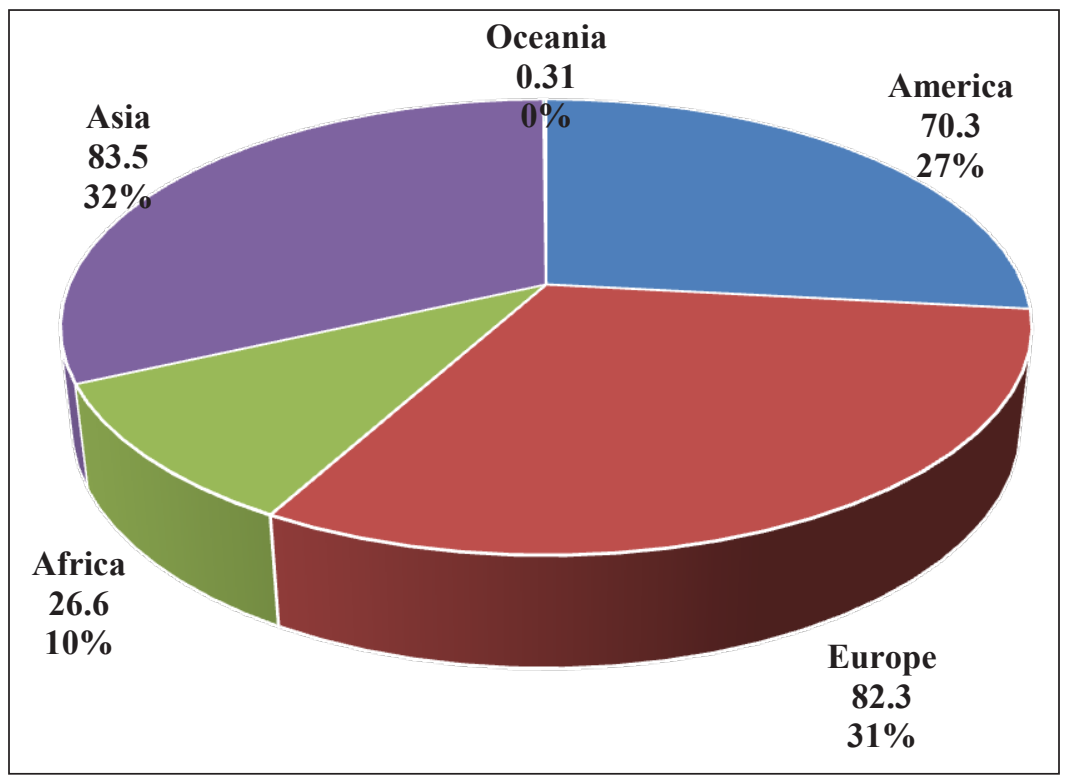

Sources: UNDESA (2019).

Fig. 2: Share of international migration stock by different regions in the year 2019; values are in million

Uttar Pradesh, Bihar, Odisha have more number of out-migrants (Handral et al. 2018).

A survey group found that the migration took place from eastern part of the country to the cities in western part, Delhi and to the southern India. For some other reasons also, migration takes place, for example, a significant number of workers migrated to the city of Surat in Gujarat for diamond industry (Upadhyaya, 2015). The National Sample Survey and Census 2011 of India reveal that about 28.3\% 
were the migrants among total workforce in India (MHUPA, 2017). There were about 15 million shortterm workers who migrated for temporary jobs and also in circulatory nature (Keshri and Bhagat, 2012).

Table 1: Overseas Indian migration to different countries in the world, total of non-resident Indians and persons of Indian origin; listed those countries where the number is more than 100 thousands

\begin{tabular}{|c|c|c|}
\hline S1. No. & Country & $\begin{array}{l}\text { Overseas Indian } \\
\text { population ('000) }\end{array}$ \\
\hline 1 & Australia & 496.00 \\
\hline 2 & Bahrain & 326.66 \\
\hline 3 & Canada & 1689.05 \\
\hline 4 & Fiji & 315.19 \\
\hline 5 & France & 473.52 \\
\hline 6 & Germany & 185.08 \\
\hline 7 & Guyana & 299.38 \\
\hline 8 & Indonesia & 120.00 \\
\hline 9 & Italy & 203.05 \\
\hline 10 & Kuwait & 1029.86 \\
\hline 11 & Malaysia & 2987.95 \\
\hline 12 & Mauritius & 894.50 \\
\hline 13 & Myanmar & 2009.20 \\
\hline 14 & Nepal & 600.00 \\
\hline 15 & Netherlands & 240.00 \\
\hline 16 & New Zealand & 240.00 \\
\hline 17 & Oman & 781.14 \\
\hline 18 & Philippines & 120.00 \\
\hline 19 & Qatar & 746.55 \\
\hline 20 & Saudi Arabia & 2594.95 \\
\hline 21 & Singapore & 650.00 \\
\hline 22 & South Africa & 1560.00 \\
\hline 23 & Sri Lanka & 1614.00 \\
\hline 24 & Suriname & 237.20 \\
\hline 25 & Thailand & 195.00 \\
\hline 26 & Trinidad \& Tobago & 556.80 \\
\hline 27 & UAE & 3425.14 \\
\hline 28 & UK & 1764.00 \\
\hline 29 & USA & 4460.00 \\
\hline \multicolumn{2}{|c|}{ Overseas total (in } & 32100.34 \\
\hline
\end{tabular}

Sources: GoI (2019), Ministry of External Affairs, Government of India, New Delhi.

Table 2: Share of each category of total internal migration in India

\begin{tabular}{lll}
\hline Migration category & $\begin{array}{l}\text { \% of total } \\
\text { migration as per } \\
\text { Census 2001 }\end{array}$ & $\begin{array}{l}\text { \% of total } \\
\text { migration as per } \\
\text { Census 2011 }\end{array}$ \\
\hline Rural-rural & 56.3 & 47.4 \\
Rural-urban & 21.8 & 22.1 \\
Urban-rural & 6.6 & 7.9 \\
Urban-urban & 15.2 & 22.6 \\
\hline Total & $\mathbf{1 0 0 . 0}$ & $\mathbf{1 0 0 . 0}$ \\
\hline
\end{tabular}

Sources: Census of India, 2001, 2011. Office of the Registrar General E Census Commissioner, India, Ministry of Home Affairs, Government of India, https://www.censusindia.gov.in

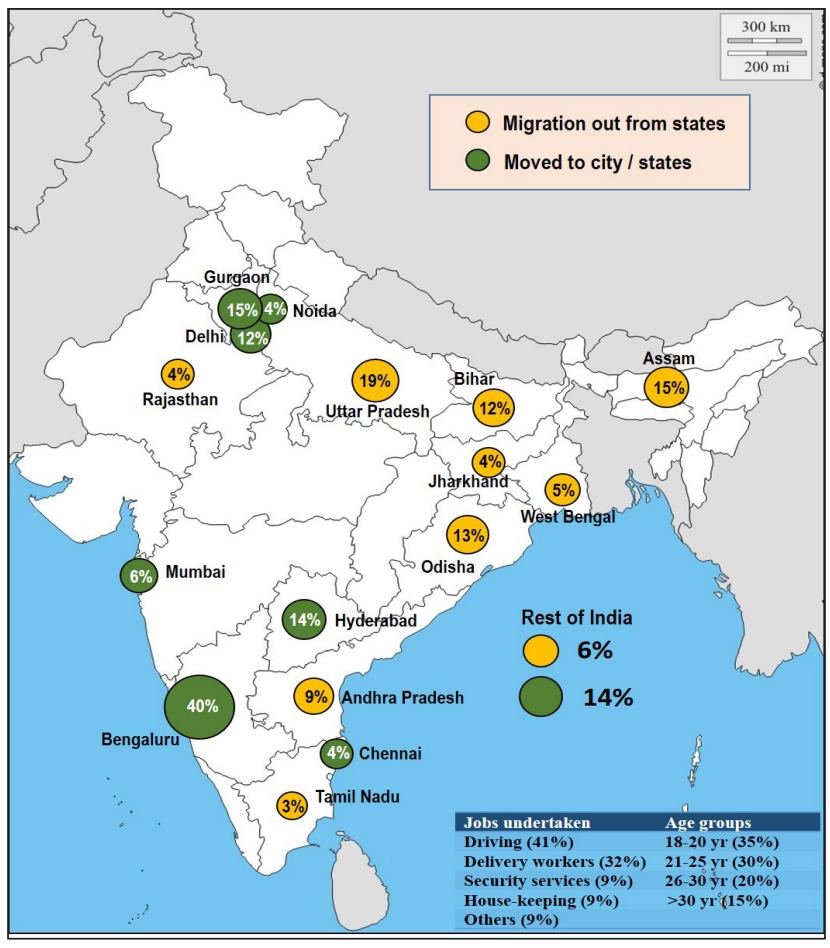

Sources: Basu (2019).

Fig. 3: Indian migrant workers: migration-out from states and moved to other city/ states

\section{RESULTS AND DISCUSSION}

\section{Impacts of COVID-19 pandemic on migrant workers}

The COVID-19 pandemic has impacted both international and internal migrants in South Asia region. Initially about 1500 overseas Indians including migrant workers were evacuated from China, Japan, Italy and Iran during February to April 2020; then about 61,000 have returned from many other countries by the Government of India special initiative, 'Vande Bharat Mission' (Fig. 4). In India, the livelihoods of a large population of internal migrants $\sim 40$ million have been affected due to COVID-19 pandemic (PTI, 2020). About 120-140 million have returned back to their origin. Not only the health crisis, lock-down caused inflicted damages on working lives of migrants, socio-economic conditions, job-loss, slumping in all activities, uncertainty in livelihood of migrants and wage loss (Bhagat et al. 2020). It was reported that 500-600 thousands of migrant workers walked on foot to their villages, 8.4 million were given food by the Government and NGOs, 1.03 million 


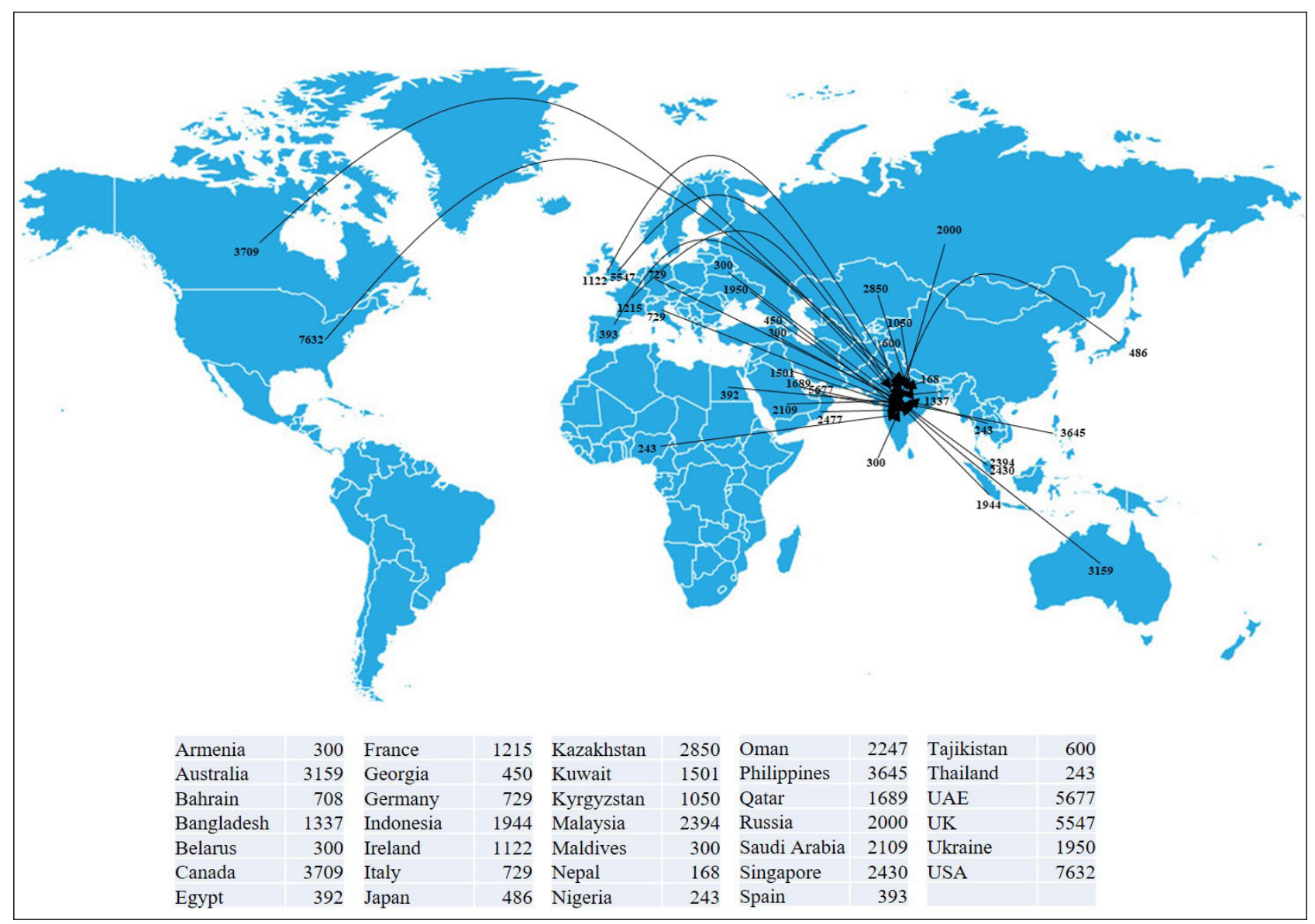

Sources: MoEA (2020), Government of India

Fig. 4: Indian migrants returned to India from different countries due to COVID-19 pandemic

were in shelter homes, 1.5 million were given food and/ or shelter by employers, while 22,567 shelter camps were created (Jha, 2020). There has been adverse impact on the farming community who are engaged in agriculture and allied activities. Risks are associated with food systems, and agricultural growth experienced deceleration in the medium and long-term (Chand, 2020). The value chains and food supply got disrupted due to prolonged impacts of COVID-19. The returnees were given priority to avert destabilizing effects; and they should be given value to their contributions.

Now, it has become certain that the world will not be the same. The challenges ahead are to cope up with migration of work force, reduction in remittances, protecting livelihoods of migrant labours, providing them income through employment (FAO, 2020). Therefore, the need of the hour is to strengthen selfsufficiency and self-reliance. Agriculture sector in India has potential to stand amid the crisis to supply foods to its large population still following the protocols of standard operation procedures (SOPs) viz. use of masks, hand washing and sanitization, and social distancing. The lessons learnt are to the preparedness against any such odds to the normalcy of livelihoods. It is required to ensure a better coordination between the central Government and the state's administration, disseminating the advisories to the farmers through electronic media. In this regard, the apex agricultural organization that is, Indian Council of Agricultural Research (ICAR) has played a significant role through its different Institutes and village level farm science centres i.e. Krishi Vigyan Kendra (KVK) spread all over the country, and raising fund allocation for the agriculture and allied sectors (Chand, 2020).

\section{Evidence-based approaches and potential options to develop self-reliant farming}

\section{(a) Strategic re-integration and group farming}

Group farming is a viable option for marginal $(<1$ 
ha) and small land holders (1-2 ha). These categories of land holders share about $86 \%$ of total 145.73 million operational land holders with average holding size of $1.08 \mathrm{ha}$, and about $40 \%$ workers of total population in India (DAC\&FW, 2019). It would be better to manage farming activities collectively than individual family farm concept and practices. This approach would provide farmers a higher scale of economic returns. Pooling of cultivable land, capital and labour force would be required. Collective actions should address the challenges of the common pool resources. By that way, comparatively larger farm entity would be created. There will be effective and productive utilization of skills and expertise of the farm working force. The group size, heterogeneity and risk of free riding should be taken into consideration. In a study in Kerala and Telangana, India it has shown that group farming outperformed individual family farming (Agarwal, 2018), whereas in Telangana, it was equivalent in net economic returns. Of course there are several underlying factors to its successful operation. A firm commitment and efforts will form the group a more profitable one than individual farm. A strong and dedicated leadership would be required, with sharing of labour requirement, cost of inputs and collective management of leased-in lands. Although cultivation of commercial crop like banana was better in Trissur, group farming have ample potential for other food crops as well, as for rice in Alappuza, Kerala. It has scope to empower farm women also, who can find an alternative source of income and engagement outside the domain of familial affairs (Agarwal, 2019). It has been proved that women managed farms were more successful in Kerala.

The group farming is successful in Tumajore village of Sundargarh district in Odisha, India with 74 households including 20.72\% ST, 2.96\% SC (Gupta and Parida, 2013). Primarily the area was rainfed, and lacking irrigation facilities. Agriculture production was not sufficient to support their families throughout the year; food insecurity was very high among landless, small and marginal farmers. Rice was the only crop; vegetable cultivation was not taken up largely. Farmers began an organization with all households. With the interest of farmers and people, they started cultivation of pointed gourd, a vegetable in eastern India, in the form of a group. A patch of 2.5 ha area was leased-in and converted into successful pointed gourd cultivation near a perennial water stream, otherwise it remained barren. Initially with 19 households, 7.72 tonnes of this vegetables worth INR $1,00,760$. With their success as a model, later on another 66 households joined the group and, and now about 10-12 ha of the same type of land is cultivated with successful pointed gourd cultivation; the produce have carved a niche in neighbouring states like Chhattisgarh, Madhya Pradesh and in the local areas of Odisha. This community farming approach has strengthened self-sufficiency, selfreliance and livelihood of people with its primary focus on vegetable cultivation.

Community farming can be encouraged by providing leased lands, and supported by local government or the Panchayats in India. The volunteer-driven members of a neighbourhood may form a community. In the name of community gardens, it is quite popular in many European countries, which they call those as allotment garden, and in USA about 16,000 community supported farms (Chakravarty, 2019). A considerable amount of energy and time should be devoted by the members. Before the crop season, the group of farmers form the plan of cropping, costs involved and own wages; then the community contacts with consumers nearby to buy the produce throughout the growing and harvesting seasons; the system of home-delivery or delivery to a common-point is ensured. By that way consumers are also integrated into the community. In south Goa, two groups of farmers viz. Majorda-Pate Xetkari Sounstha and vegetable farmers association of Fatorda have started community farming in 10.4 ha land with 18 farmers and 3.18 ha land with 41 farmers, respectively; rice during rainy season and vegetables and cowpea in post-rainy season (Sayed, 2019). These are some examples for potential 'Start-up' or 'Make in India' programme by the rural youths and farmers, who can manage farming from production to marketing in the form of a community togetherness; this would be effective for the returnees to get re-employed along with native small and marginal farmers in this post-COVID-19 pandemic era and also beyond. 


\section{(b) Food processing and micro-enterprises development option}

Food processing industries have ample potential to provide employment and generating a stable income to the distressed people in post- COVID-19 era. It has strong linkages with rural economy, because of the fact that raw materials are produced at the village level. Scientific back-up is not lacking in India. It is especially very important in India because the country is leading in the production of pulses, jute and milk, ranked second in production of vegetables and fruits, third in cereals in the world (DAC\&FW, 2019), and the largest producer of coconuts, cashewnut and tea. The primary processed foods are milled rice, wheat flour, corn flour, pulses, spices, salt, fruits, vegetables, edible oils, packed milk, tea, coffee, cocoa etc. The secondary or processed products include: processed fruits, processed vegetables, jam, jelly, pickles, squashes, dairy products like ghee, cheese, paneer, curds, butter, chocolates, processed fish and marine products, papad, snacks and confectionary, chips, processed poultry products, aerated and malt beverages etc. (Rais et al. 2013). In addition, traditional products will gear-up these industries viz. traditional sweets which are also accepted widely in other south-Asian countries, Africa, USA, Canada and UK, and new whey products. It will have significant impact on socio-economic growth in the country. In rural areas, it is the most appropriate avenue in this post-COVID-19 erato provide employment to rural masses. It will generate re-employment of return migrants, thereby the livelihood of rural people and the rural economy would be strengthened. In an estimate earlier, food processing sector employs about 13 million people directly and 35 million indirectly (MoFPI, 2011). Education level of most of the employees (about $80 \%$ ) is $10^{\text {th }}$ standard or below. Only thing, which is required to be done now is, prospective youths should be trained and the Government should support for initial investment in establishment of these micro-industries.

The fragmented nature of food processing industries, which are dominated by unorganized sectors (Rais et al. 2013), should be consolidated and strengthened especially to catalyse economic growth during COVID-19 post-pandemic. This would be very important step because unorganized sectors contributes about $42 \%$ of the outcomes. As per ASI (2019) data, there were about 39,748 food-processing industries in 2016-17 under organized sector (those which are not registered). However, there is low percentage of enterprises under food processing industries in organized sector (Dhanya et al. 2020). Most of the organized enterprises belong to the states viz. Andhra Pradesh, Telangana and Tamil Nadu, whereas most of the unincorporated food-processing units are present in Uttar Pradesh and West Bengal. In terms of employment also, the unorganised sector dominates. Employment generation is about 1.77 million in registered processing entities, which is $11.4 \%$ of total employment in registered manufacturing sectors. State-wise share in food-processing industries show that the number of industries, employment generation and gross value added are more in top 5-states viz. Maharashtra, Uttar Pradesh, Karnataka, Gujarat, Andhra Pradesh; whereas eastern Indian states have less development in food-processing industries, hence there is ample scope to develop micro-enterprises.

The migrant workers may be given opportunity to be engaged in these industriesin this postCOVID-19 pandemic. The adverse impact of lockdown have been overcome by the people through evolving their own ways and means. For example, the success story of north-eastern India is worth to mention here. During the COVID-19 lockdown, people realised how important was the homemade fruit-wine making in Meghalaya (Agarwal 2020). Fruit-wine is very popular in the region for domestic as well as international markets. Fruits like pears, banana, pineapple, strawberry, peach and plums are used for fruit-wine making at home. Those were brewed during the COVID-19 lockdown period. The local wild tangy fruits are: 'Sohiong' (Prunus nepalensis), also known as Meghalaya black cherry, 'Sohmon (Meyna laxiflora), 'Sophie' (Myrica esculenta), 'Sophie nam' (Myrica nagi) which is the red variety of 'Sophie', 'Sohshang' (Eleagnus latifolia), and 'SohLyngdkhur' (Morus indica). 'Soh" means fruit in 'Khasi' language. These fruits are indigenous to Khasi and Jayantia hills of north-east India. In the lockdown period, State Government announced giving license to the farmers for this home-made livelihood option of the people. Lessons learnt may be extended to other areas in the country and in the globe. 
However, the need is skill development and training to the human forces for these industries to grow further. In this post-COVID-19 era, opportunities to engage them would be required. It would be possible through investments by Government towards skill development, and the associated councils would be of great help to provide training from National Skill Development Council (NSDC) and Agricultural Skills Council of India (ASCI). The technical support for skill development should be obtained from National Institute of Food Technology, Entrepreneurship and Management (NIFTEM) and the Indian Institute of Food Processing Technology (IIFPT). 'Pradhan Mantri Kisaan Sampada Yojana' would be very effective to boost efficiency in this sector (Dhanya et al. 2020). The economic turndown will be stalled and opportunities may be created through 'Make in India' and 'Skill India' programmes (MHUPA, 2017).

\section{(c) Strengthening farmer producer organizations (FPOs)}

FPO is a legal entity which is formed by the producers i.e., farmers, fishermen, rural artisans, weavers, craftsmen (NABARD, 2015). It can be a producer company or a cooperative society, which provides sharing of profits among members. Small Farmers' Agribusiness Consortium (SFAC) provides support to promote FPOs. Basically it is a legal organization of the primary producers i.e. the farmers, produce from agriculture, horticulture, fisheries and other allied activities of rural people. This also includes handlooms, handicrafts, byproducts of ancillary activities. Different subactivities are: input procurement, sharing of technology, innovations and market information, facilitating finance, storage of produce, primary processing of farm produce, packaging, labelling, quality control, marketing and export etc. A total of 910 FPOs with 8,84,709 farmers are existed in different states and UTs in India (Table 3). There are several success stories or evidences available in India. Recently about 72 FPOs from 8 States have traded 4,824 tonnes of fruits, vegetables and other crops at INR 14.07 crore, with due compliance with COVID-19 lockdown norms. This effort supported marginal and small farmers for their produce to market and fetch sizable income (SFAC, 2020).Promoting sustainable agriculture would be essential through farmer producer organizations, effective credit giving, institution development and innovative initiatives.

Table 3: Farmer Producer Organizations (FPOs) in different states/UT of India (as on 29.02.2020)

\begin{tabular}{|c|c|c|}
\hline States/ UTs & $\begin{array}{l}\text { Total number of } \\
\text { farmers }^{\sharp}\end{array}$ & $\begin{array}{l}\text { Total number } \\
\text { of FPOs\& }\end{array}$ \\
\hline \multicolumn{3}{|l|}{ North India } \\
\hline Jammu \& Kashmir & 8061 & 2 \\
\hline Himachal Pradesh & 6850 & 8 \\
\hline Punjab & 6000 & 7 \\
\hline Haryana & 12750 & 23 \\
\hline Delhi & 3500 & 4 \\
\hline Rajasthan & 60500 & 50 \\
\hline Uttarakhand & 6000 & 7 \\
\hline Uttar Pradesh & 56000 & 58 \\
\hline Total & 159661 & 159 \\
\hline \multicolumn{3}{|l|}{ Western India } \\
\hline Maharashtra & 104500 & 105 \\
\hline Gujarat & 24000 & 25 \\
\hline Goa & 1750 & 2 \\
\hline Madhya Pradesh ${ }^{1}$ & 150000 & 149 \\
\hline Total & 280250 & 281 \\
\hline \multicolumn{3}{|l|}{ South India } \\
\hline Andhra Pradesh & 13000 & 16 \\
\hline Telangana & 29998 & 26 \\
\hline Tamil nadu & 17000 & 17 \\
\hline Karnataka & 128500 & 126 \\
\hline Total & 188498 & 185 \\
\hline \multicolumn{3}{|l|}{ Eastern India } \\
\hline Assam & 10500 & 18 \\
\hline Bihar & 35000 & 38 \\
\hline Jharkhand & 12000 & 10 \\
\hline Chhatisgarh & 29000 & 28 \\
\hline Odisha & 38900 & 41 \\
\hline West Bengal & 90500 & 89 \\
\hline Total & 215900 & 224 \\
\hline \multicolumn{3}{|l|}{ North-East India } \\
\hline Arunachal Pradesh & 4750 & 6 \\
\hline Manipur & 6950 & 8 \\
\hline Meghalaya & 3750 & 4 \\
\hline Mizoram & 2700 & 2 \\
\hline Nagaland & 3750 & 4 \\
\hline Sikkim & 15750 & 30 \\
\hline Tripura & 2750 & 7 \\
\hline Total & 40400 & 61 \\
\hline Total & 884709 & 910 \\
\hline
\end{tabular}

"includes mobilized and under mobilization; Eincludes both registered and under the registration process; ${ }^{1}$ Madhya Pradesh is included under Western India; Sources: SFAC (2020b) Department of Agriculture, Cooperation and Farmers Welfare, Ministry of Agriculture and Farmers Welfare, Govt. of India, http://sfacindia. com/FPOS.aspx

\section{(d) Strengthening self-help groups (SHGs)}

Self-help groups (SHGs) are the small mass of rural poor, voluntarily form a group with the aim to 
improve social and economic conditions of members in a formal or informal manner. A common fund is created, which is used for small loans to needy members, and for productive purposes. SHGs mobilize resources, create savings habit, awareness, identify problems, find solutions, develop linkages with other stake holders, builds team work, and develop self-sustaining systems. Women empowerment is prioritized. A study in Dehradun district of Uttarakhand, India shows that SHGs empowered rural poor women with considerable development in social and cultural systems within the members. Decision making power has enhanced immensely (Rana and Ansari, 2017). Similarly, a considerable success was obtained by a self-help group of Belgaum, Karnataka, India (Pangannavar, 2014). There are several other SHGs in India, which are functional with the aim to empower rural people, especially the women farmers.

In India, according to NABARD report, there were about one crore SHGs in India covering 12 crore families, and a deposits of INR 23,324 crore as on March 31, 2019. The Government of India has announced doubling the collateral free-loans to women SHGs from 10 to 20 lakhs to enable 63 lakh SHGs, which covers 7 crore families in India (Mishra, 2020). This initiative will potentially strengthen rural economy. During COVID-pandemic, SHGs have produced 132 lakh face masks, which were in short supply initially, and have provided people to shield against spread of corona virus. This has exemplified the potential of about 14,522 SHGs with 65,936 members spread across 399 districts in 24 states of India. These loan facilities will boost rural demand as well as consumption and the overall socio-economic conditions of rural people this post-COVID-19 era. Formalization of micro-food enterprises (MFE), with central Government's declaration of INR 10,000 crore, will support current MFEs with technical up-gradation, branding and marketing, to support FPOs, SHGs, and cooperatives aiming at boost its production and export.

\section{(e) Adopting integrated farming systems (IFS) for agricultural multi-enterprises development}

Integrated Farming System (IFS), also known as integrated bio-systems, is an interdependent, interrelated often interlocking production systems based on crops, fish, animals and related subsidiary enterprises in such a way that maximize the utilization of nutrients of each system and minimize the negative effects of these enterprises on environment. Compartmental approach to farming puts it into a vicious cycle of risks, whereas integrated approach leads to minimum-risk-optimum-profit and maximum environmental benefits. Various IFS such as ricefish-on dyke horticulture-vegetable (Mohanty et al. 2004), integrated system of rice intensification (ISRI) with fish and horticulture crops (Thakur et al. 2015), pond-based IFS (Mandal et al. 2016), self-reliant agri-based IFS (Rautaray et al. 2020) are evidence-based and can be popularised to make farming a viable, profitable and replicable system in Indian context. From water management point of view, aquaculture-based IFS integrating aquaculture (carp polyculture), agriculture (kharif rice followed by green gram and vegetables), on-dyke horticulture (banana and papaya) and poultry 'Vanaraja' have been found to be one of the most water saving, sustainable, productive and replicable model. These systems as a whole, generate net profit of about ₹ 110000- 170000 per ha with an output value to cost of cultivation (OV-CC) ratio of 2.7-2.8 and net consumptive water productivity of ₹ 9.8-16.2 per $\mathrm{m}^{3}$ of water. Further, this system helps in enhancing water productivity, water use efficiency and minimize water footprint when fish and prawn are added as a major component (Mohanty et al. 2009).

Other components of IFS viz. animal husbandry, bee keeping and herbal cultivation should be taken into active consideration with the financial support of the Government of India, as has been declared in this COVID-19 period; INR 15,000 crore for animal husbandry, INR 4,000 crore for herbalmedicinal plants cultivation and INR 500 crore for beekeeping initiatives (MoF, 2020). Water is the lifeblood of all ecosystems. This is essential for food production systems. Therefore, approaches to effective water management should be prioritised. Recommendations of FAO (2020b) are: making water and sanitation programmes a priority in the development plans, monitoring and assessing water resources including its quality through remotely sensed platforms, effective measures to increase water productivity in agricultural, horticultural and animal-based systems, and overall creating 
of healthier ecosystems, even beyond COVID-19 post-pandemic.

\section{(f) Practicing integrated aquaculture farming}

Integrated aqua-culture farming activities have ample potential not only to enhance productivity, but also to generate employment opportunities, increase income and provide nutritional security to resource poor farming community and distribute the risk (both biological and economical), since two or more subsystems are involved instead of a single commodity farming system. There are research-based information that integrated fishfarming would accrue economic benefits. For example, shrimp polyculture with brackishwater fish/ monoculture (Mohanty et al. 2017a, 2018), and crab-fish polyculture (Mondal et al. 2020) in coastal belt of India have been found to be very lucrative and promising. Similarly, carp polyculture (Mohanty et al. 2017b), freshwater prawn culture, minor carp culture and culture of small indigenous species (SIS) in non-saline areas are advisable for small and marginal farmers. Resource poor farmers, unemployed youths and migrant labourers can venture in to these activities, taking advantage of already available government schemes and recently announced special revival package for aquaculture sector due to COVID-19 pandemic. In this aspect, the response of the central Government, announcement of Pradhan Mantri Matsya Sampada Yojana, the allocated fund of INR 200,000 million should be effectively mobilized towards infrastructure development i.e., fishing harbours, cold chains, market to increase fish production in marine, inland fisheries and aquaculture activities in the country.

\section{CONCLUSION}

There had been considerable disruption in every aspect of human life due to COVID-19 pandemic all over the world. The economic activities affected due to complete lockdown for a considerable period of time, then partial and intermittent stoppages of activities. Large numbers of migrant workers have returned to their native places, and also some of them have resumed work in this post-COVID time. However for the long-term, migrant workers should be given personal security, well-being and stability ignoring their under-utilization. Strategic reintegration with native people should be made; crucial role to play by local Governments i.e. village panchayat systems. Overall, there is dire need for job creation and potential employment at the local level, and in a self-sustenance and resilient mode against different agents of perturbation and stresses to the systems. There are several challenges ahead to regain the normalcy so that a positive economic growth is achieved in this post-COVID period.

Self-reliant farming systems approach by the small and marginal land holders, integrated with return migrant workers, would show the path towards sustainable development in farming community and other rural people. Group farming or the partnership approach will pave the way towards self-reliance and economic growth of distressed farmers in this post-COVID-19 era. Whereas FPOs and SHGs are playing key roles, those organizations should be strengthened further by providing more financial support and liberalised governance. The input supply like seeds, fertilizers and others should be ensured to the farmers for the cropping seasons. Labour requirement may be met through return migrants to the villages. There is the need for cluster-based promotion of agro-commodities. Vocational training, skill development and microfood enterprises initiatives will be required for the rural youths, farmers and young migrant workers. Cold chain maintenance in food supply systems and marketing reforms would help in better price realization by the producers. There is need for enhancement of existing cold storages capacity, and creating new infrastructures for storage of vegetables and fruits for year-round supply to market, and also to consumers; marketing reforms by subsidized and liberalized inter-state transport facilities.

Government schemes should be effectively utilized by developing suitable mechanisms i.e. direct transfer of funds to farmers and rural youths for agriculture and allied sectors towards self-reliant mission India announced by the Government in fight against COVID-19 pandemic. Food microenterprises development can be achieved by formalizing about 910 FPOs (SFAC, 2020b) and about 10 million SHGs in India (Mishra, 2020). Landless workers along with farmers may form clusterbased cooperatives for crops and commodities viz. rice, jute, potato, mango, bamboo, chilli etc., which 
will create more employment, boost production, marketing and better livelihood to rural people and the famers. Processing of several agri- and animalbased products can be developed at the rural level, and also for huge export earnings. With the support of Government schemes, integrated farming systems including herbal plants cultivation, bee-keeping, animal husbandry will provide stability in rural economy, and aquaculture farming to boost fish production and earnings through export. This will revive battered economy due to adverse impacts of COVID-19 pandemic, and strengthen Indian agriculture in the long-run.

\section{REFERENCES}

Agarwal, B. 2018. Can group farms outperform individual family farms? Empirical insights from India. World Development, 108: 57-73.

Agarwal, B. 2019. Does group farming empower rural women? Lessons from India's experiments. J. Peasant Studies, 31 Jul 2019, https://doi.org/10.1080/03066150.20 19.1628020

Agarwal, T. 2020. For fruit winemakers of Meghalaya, the pandemic has brewed some good news. The Indian Express, May 21, 2020.

ASI, 2019. Annual Survey of Industries, 2016-17 Summary Results for factory Sector, Ministry of Statistics and Programme Implementation, NSSO, Data Processing Division, Industrial Statistics Wing, Kolkata, Government of India.

Basu, Sreeradha D. 2019. Migrant workers: Where they come from, where they go. The Economic Times, Jan 08, 2019.

Bhagat, R.B., Reshmi, R.S., Sahoo, H., Roy, A.K. and Govil, D. 2020. The COVID-19, Migration and Livelihood in India. A Background Paper for Policy Makers, IIPS Analytical Series on Covid 19: Paper 1, April 14, 2020. International Institute for Population Sciences, Mumbai.

Census of India, 2001, 2011. Office of the Registrar General \& Census Commissioner, India, Ministry of Home Affairs, Government of India, https://www.censusindia.gov.in.

Chakraborty, I. and Maity, P. 2020. COVID-19 outbreak: Migration, effects on society, global environment and prevention. Sci. Total Env., 728: 138882.

Chakravarty, S. 2019. Fixing the food system with Community Farming. The New Indian Express, Kochi, 25 September, 2019. https://www.newindianexpress.com/cities/kochi/ 2019/sep/25/fixing-the-food-system-with-communityfarming-2038597.html

Chand, R. 2020. COVID-19 and food system risks in India. International Food Policy Research Institute (IFPRI), South Asia, New Delhi, COVID-19 blog series, May 11, 2020.

DAC\&FW, 2019. Agriculture Statistics at a Glance-2018. Department of Agriculture, Cooperation and Farmers
Welfare, Ministry of Agriculture and Farmers Welfare, Government of India

Dhanya, V., Shukla, A.K. and Kumar, Rishabh. 2020. Food processing industry in India: Challenges and potential. Department of Economic and Policy Research, Reserve Bank of India, RBI Bulletin March 2020: 27-41.

FAO, 2020. Migrant workers and the COVID-19 pandemic. Migrant workers and the COVID-19 pandemic. Lead Author, Rapone, Cristina, Ion Bulgac, Economic and Social Development Department, Food and Agriculture Organization of the United Nations. Rome. https://doi. org/10.4060/ca8559en.

FAO, 2020b. Integrated agriculture water management and health. Food and Agriculture Organization of the United Nations, Rome. https://doi.org/10.4060/ca8712en.

FAO. 2020b. Integrated agriculture water management and health. Food and Agriculture Organization of the United Nations, Rome. https://doi.org/10.4060/ca8712en.

GoI 2019. Overseas Indians (total of non-resident Indians and persons of Indian origin), Ministry of External Affairs, Government of India, New Delhi, accessed on 17.05.2020) https://mea.gov.in

Gorbalenya, A.E., Baker, S.C., Baric, R.S., de Groot, R.J., Drosten, C. and Gulyaeva, A.A. 2020. Severe acute respiratory syndrome-related coronavirus: the species and its viruses - a statement of the Coronavirus Study Group. Bio Rxiv, https://doi.org/10.1101/2020.02.07.937862 Feb 11.

Gupta, S. and Parida, G. 2013. Group Farming: A community farming initiative. LEISA India, 15(2): 34-36.

Handral, A.R., Anbukkani, P. and Kumar, P. 2018. Internal labour migration in India: Recent trends and patterns. Ann. Agric. Res., New Series, 39: 1-8.

ILO, 2017. Global Estimates on International Migrant Workers- Results and Methodology- Second Edition (reference year 2017). ILO Labour Migration Branch and ILO Department of Statistics, International labour Organization, Geneva, p.78.

ILO, 2020. Protecting migrant workers during the COVID-19 pandemic, Recommendations for policy-makers and constituents. Policy Brief, April 2020. International labour Organization, Geneva.

Jha, S. 2020. Covid-19 impact: Government begins mapping of migrant workers for relief measures. Business Standard, April 09, 2020.

Keshri, K. and Bhagat, R.B. 2012. Temporary and Seasonal Migration: Regional Pattern, Characteristics and Associated Factors. Econ. Pol. Weekly, XLVII(4): 81-88.

Mandal, KG., Mohanty, RK., Ghosh, S., Kundu, D.K., Raychaudhuri, M., Padhi, J., Majhi, P., Sahoo, D.K., Kumar, A. and Ambast, S.K. 2016. Participatory Water Management and Integrated Farming in a Canal Command. Res. Bulletin 75, ICAR-IIWM, Bhubaneswar, p. 64.

MHUPA, 2017. Report of the Working Group on Migration. Ministry of Housing and Urban Poverty Alleviation, Government of India, New Delhi, January 2017. 
Mishra, H.H. 2020. Self-Help Group potential can boost rural production and consumption. The Economic Times, April 06, 2020.

MoEA, 2020. Vande Bharat Mission. Ministry of External Affairs, Government of India https://mea.gov.in/vandebharat-mission-list-of-flights.htm (accessed on 19.05.2020)

MoF, 2020. Aatma Nirbhar Bharat Abhiyan (Self-reliant India Mission) Part-3: Agriculture, Ministry of Finance, Government of India, Press Information Bureau, Delhi, May 17, 2020.

MoFPI, 2011. Strategic Plan for Food Processing Industries in India, Ministry of Food Processing Industries, Government of India, New Delhi.

Mohanty, R.K., Ambast, S.K., Panda, D.K., Thakur, A.K. and Mohanty, S. 2017b. Density-dependent water use in carp polyculture: Impacts on production performance and water productivity. Aquaculture, 470: 32-39.

Mohanty, R.K., Ambast, S.K., Panigrahi, P., Thakur, A.K. and Mandal, K.G. 2018. Enhancing water use efficiency in monoculture of Litopenaeus vannamei: Impacts on pond water quality, waste production, water footprint and production performance. Aquacul. Engg., 82: 46-55.

Mohanty, R.K., Jena, S.K., Thakur, A.K. and Patil, D.U. 2009. Impact of high-density stocking and selective harvesting on yield and water productivity of deepwater rice-fish systems. Agric. Water Manage., 96: 1844-1850.

Mohanty, R.K., Mishra, A., Ambast, S.K., Mandal, K.G., Panda, D.K. and Panigrahi, P. 2017a. Effects of various shrimp (Penaeus monodon) densities on their growth, water and sediment quality, and water budget. Aquacul. Int., 25: 2161-2176.

Mohanty, R.K., Verma, H.N. and Brahmanand, P.S. 2004. Performance evaluation of rice-fish integration system in rainfed medium land ecosystem. Aquaculture, 230: 125-135.

Mondal, A., Bhattacharya, S., Mitra, A., Sundaray, J.K. and Mohanty, R.K. 2020. Performance evaluation of mud crab Scylla olivacea (Herbst, 1896) co-culture with different fish species in confined brackish water ponds. Aquaculture, 522.

NABARD, 2015. Farmer Producer Organizations- Frequently Asked Questions (FAQs). Farm Sector Policy Department \& Farm Sector Development Department, National Bank for Agriculture Mumbai and Rural Development (NABARD) Head Office, Mumbai, pp. 158.

Pangannavar, A.Y. 2014. A Research Study on Development of Self-Help Groups in Belgaum District. PRAGATI: J. Ind. Econ., pp. 61-76.
PTI, 2020. Lockdown in India has impacted 40 million internal migrants: World Bank. Press Trust of India, The Economic Times, Apr 23, 2020.

Rais, M., Acharya, S. and Sharma, N. 2013. Food processing industry in India: S\&T capability, skills and employment opportunities. J. Rural Develop., 32(4): 451-478.

Rana, K. and Ansari, M.A. 2017. Self-Help Group \& Woman Empowerment: A Study on some selected SHGs in Dehradun district. Int. J. Curr. Sci. Tech., 5(12).

Rautaray, S.K., Dubey, R., Raychaudhuri, S., Pradhan, S., Mohanty, S., Mohanty, R.K. and Ambast, S.K. 2020. Sustainable agriwaste management at farm level through self-reliant farming system. Waste $M g t$ E Res., DOI: $10.1177 / 0734242 \times 20920350$

Sayed, N. 2019. In South Goa, good crop boosts community farming. The Times of India. Jun 25, 2019. https:// timesofindia.indiatimes.com/city/goa/in-south-goa-goodcrop-boosts-community-arming/articleshow/69934498. $\mathrm{cms}$

SFAC, 2020. Covid Agri News Bulletin. Small Farmers' Agri-Business Consortium. Department of Agriculture, Cooperation and Farmers Welfare, Ministry of Agriculture and Farmers Welfare, Govt. of India, May 6, 2020.

SFAC, 2020b. Small Farmers' Agri-Business Consortium, Department of Agriculture, Cooperation and Farmers Welfare, Ministry of Agriculture and Farmers Welfare, Govt. of India, http://sfacindia.com/FPOS.aspx

Thakur, A.K., Mohanty, R.K., Singh, R. and Patil, D.U. 2015. Enhancing water and cropping productivity through Integrated System of Rice Intensification (ISRI) with aquaculture and horticulture under rainfed conditions. Agric. Water Manage., 161: 65-76.

UNDESA, 2019. International Migration Stock 2019. Population Division. International Migration, United Nations Department of Economics and Social Affairs, https://www.un.org/en/development/ desa/population/ migration/data/index.asp (accessed on 16 May 2020).

UNDP, 2020. Socio-economic impact of COVID-19. United Nations Development Programme (UNDP), https://www. undp.org/content/undp/en/home/covid-19-pandemicresponse/socio-economic-impact-of-covid-19.html, (accessed on 25 May 2020).

Upadhyaya, H. 2015. A Study of Migration of Workers in India. SAMVAD: SIBM Pune Res. J., 10: 59-66. 